\title{
Pizotifen for the treatment of migraine. A systematic review and meta-analysis
}

\author{
Yara Dadalti Fragoso (D), Giullia C. Mangas Lopes iD, Giovanna Marcilio Santos (D), Paula Carturan (D), \\ Ana Luiza C. Martimbianco
}

Universidade Metropolitana de Santos, São Paulo, Brazil

\section{$\triangle$}

Yara Dadalti Fragoso

Universidade Metropolitana de Santos (UNIMES)

Avenida Conselheiro Nebias,

536 - Encruzilhada, Santos - SP,

$11045-002$

Phone: +55 (13) 3228-3400

yara@bsnet.com.br

Edited by:

Marcelo Moraes Valença

Keywords:

migraine

pizotifen

headache

systematic review

evidence-based medicine

\begin{abstract}
Introduction

Pizotifen is an oral drug developed many years ago for the prophylaxis of migraine. Trials on pizotifen are decades old, and there has never been a systematic review and meta-analyses of data from these clinical studies.

Methods

This is a systematic review and meta-analyses on pizotifen's efficacy and safety for prophylactic migraine treatment. We considered for inclusion only randomized clinical trials (RCTs). A comprehensive electronic search was performed without language, date or publication status restrictions in the formal electronic databases, clinical trial registration platforms and grey literature.

Results

There were eight RCTs of pizotifen compared either to placebo or to other drugs. Very low certainty of evidence showed that pizotifen seems to be superior to placebo regarding clinical symptoms improvement (Relative risk [RR] 6.00; 95\% Confidence interval [Cl] 1.63 to 22.03; $p=0.007$ ), but not inferior to naproxen, flunarizine, valproate or clonidine. Weight gain was the most frequent adverse event of pizotifen but there was no difference with placebo (RR 1.92; 95\% Cl 0.30 to 12.38; 2 RCTs; 142 participants; $12=67 \% ; p=0.49$ ).

Conclusion

The RCTs of pizotifen were decades old. It is a safe and potentially efficacious inexpensive drug that deserves a better designed, modern clinical trial before being dismissed as an option for migraine therapy. PROSPERO Register: CRD42020194347.
\end{abstract}




\section{Introduction}

M igraine affects over $10 \%$ of adults and can limit their activities both at home and at work.' The socioeconomic costs of migraine are remarkably high, and patients tend to overuse medications for the pain if the headache is not properly treated. ${ }^{2}$ This disease is an important cause of absenteeism and presentism at work, missed days at school and excessive numbers of medical consultations and examinations. ${ }^{3}$ Although several medications have been used for prophylaxis of migraine attacks, only two classes of drugs presently commercialized have been specifically developed for this condition. One of the drugs is the relatively old pizotifen and the other is the monoclonal antibody (MAb) anti-CGRP. Small oral molecules with anti-CGRP effect are undergoing clinical trials.

Anti-CGRP monoclonal antibodies have a strong placebo and weak nocebo effect. ${ }^{4}$ This, in addition to their good safety profile [Hou], makes these drugs successful in controlling migraine. The complicating aspect of this treatment is its cost of circa USD 200/month per patient. In places with high per capita income and/or in countries with healthcare systems providing reimbursement of the drug, use of anti-CGRP MAbs can thrive.

Pizotifen, on the other hand, costs little. The only bothersome adverse event caused by pizotifen is weight gain, which can be tolerated by some patients if they know what to expect. It is hard to find pharmacies selling branded pizotifen: it is mostly available online and at compounding pharmacies. Pizotifen may decrease migraine attacks at a fraction of the price of some other drugs. There has never been a systematic review and meta-analysis on pizotifen for the treatment of migraine.

Apart from pizotifen and anti-CGRP MAbs, other drugs are used in migraine prophylaxis, like tricyclic antidepressants, calcium channel blockers, betablockers and anticonvulsants. For all these drugs, the profile of adverse events is worse than that of pizotifen or anti-CGRP MAbs.

Should pizotifen prove to be an efficient and safe prophylactic drug for migraine, many individuals who cannot afford the expensive new therapy could benefit from the older one. Thus, the objective of this systematic review was to assess the effects (benefits and harms) of pizotifen for treating migraine in adults.

\section{Methods}

This systematic review followed the methodological recommendations of the Cochrane Handbook for Systematic Reviews of Interventions ${ }^{5}$ and the PRISMA statement (Preferred Reporting Items for Systematic Reviews and Meta-Analyses) to ensure the quality of the report. ${ }^{6}$ This systematic review protocol was prospectively registered in the PROSPERO (International Prospective Register of Systematic Reviews) platform, under the number CRD42020194347.

\section{Criteria for including studies for this review}

We considered randomized clinical trials (RCTs) with parallel design, assessing the effects (benefits and harms) of pizotifen for treating migraine in adults (over 18 years), who reported episodic or chronic migraine with or without aura. Studies that included any other headache condition were excluded if data were not presented separately for patients with migraine. The RCTs included compared any dose or scheme of pizotifen with placebo, no intervention, or another active drug treatment.

\section{Types of outcome measurements}

\section{Primary outcomes}

-Reduction of frequency and/or severity and/or duration of migraine attacks.

-Reduction of medications taken to treat a migraine attack.

-Adverse events: proportion of participants with at least one adverse event resulting from the use of pizotifen (for example, any gastrointestinal events or allergy).

Secondary outcomes:

-Patients' satisfaction and preferences.

-Tolerability of weight gain.

We considered all time points reported by the RCTs, but we only pooled similar time points: short term (up to 8 weeks of treatment), intermediate-term ( 9 to 16 weeks of treatment) and long term (over 16 weeks of treatment).

\section{Search methods for identification of studies}

A comprehensive electronic search was performed on July 20,2020 , and was updated on February 18, 2021. There were no restrictions regarding language, date or publication status. Sensitive search strategies were developed for 
the following databases: The Cochrane Central Register of Controlled Trials (CENTRAL) (via Wiley); MEDLINE (via PubMed); EMBASE (via Elsevier); Literatura Latino Americana em Ciências da Saúde e do Caribe - LILACS (via Biblioteca Virtual em Saúde - BVS); and PsycINFO (via EBSCO). We also searched for clinical trial registration platforms: Clinical Trials.gov (https://ClinicalTrials.gov/) and $\mathrm{WHO}$ International Clinical Trials Registry Platform (ICTRP) (https://www.who.int/ictrp/search/en/). The grey literature was searched via OpenGrey (http://www. opengrey.eu/). Hand searching was done by verifying the lists of references from relevant studies. Search strategies for each database were presented in the Supplementary material 1 .

\section{Data collection and analysis}

Selection of studies and data extraction

All titles and abstracts obtained through the search strategies were included in a reference management program (Endnote ${ }^{\mathbb{R}}$ ) where duplicates were removed. Two authors independently selected titles and abstracts of the references retrieved using the software Rayyan. ${ }^{7}$ All references classified as 'potentially eligible' were read in full text to confirm their eligibility.

The data extraction process was carried out by three independent authors using a pre-established data extraction form. Two other authors resolved all discordance in the selection and extraction process. When necessary, the authors of the trials included in the review were contacted for additional information.

\section{Risk of bias (quality) assessment}

Two independent authors assessed the methodological quality of the studies included using the Cochrane Risk of Bias (RoB) table ${ }^{5}$, which classify each of the following domains as presenting a high, low or unclear risk of bias: (1) random sequence generation; (2) allocation concealment; (3) blinding of participants and personnel; (4) blinding of outcome assessors; (5) incomplete outcome data; (6) selective reporting of outcomes; and (7) other potential sources of bias (for example, baseline imbalances). A third author was consulted in cases of disagreement.

\section{Data synthesis}

We planned to calculate risk ratios (RR) for dichotomous outcomes and mean differences (MD) for continuous outcomes, or the standard mean difference (SMD), if any outcome of interest had been measured using different scales or questionnaires ( $95 \%$ confidence interval). When possible (if data were available and homogeneous), treatment effects were combined using a randomeffects model meta-analysis in the Review Manager 5.4.1 software. The heterogeneity between the studies included was evaluated according to the clinical and methodological characteristics. Statistical heterogeneity was assessed through visual inspection of forest plots. We calculated $a$ chi $^{2}$ test, considering $\mathrm{p}>0.1$ as indicative of statistical heterogeneity, and an $1^{2}$ test for measuring inconsistency across studies (we defined $\mathrm{I}^{2}>50 \%$ as indicative of significant inconsistency). ${ }^{8}$

\section{Subgroup and sensitivity analysis}

We planned to assess subgroups for all primary outcomes, comparing separated results between adults and children. We also planned to conduct a sensitivity analysis in which $\mathrm{RCTs}$ with a high risk of bias (selection, detection and attrition bias) would be excluded from the meta-analysis.

\section{Publication bias assessment}

Publication bias would be investigated through analysis of funnel plots if there had been meta-analyses with at least ten studies.

Assessment of the certainty of the evidence

Two independent authors assessed the certainty of the body of evidence for primary outcomes from the main comparison: pizotifen versus placebo, using the GRADE approach (Grading of Recommendations, Assessment, Development and Evaluations). ${ }^{9}$ We summarized the evidence in the 'Summary of findings table' (SoF table) through the GRADEpro GDT platform.

\section{Results}

\section{Search results}

The results from the search strategies, retrieved 749 records. After removing 104 duplicates, 645 were analyzed using the title and abstract. Of these, 623 did not fulfil the inclusion criteria and were excluded. Twentytwo studies were analyzed using the full text, and nine ${ }^{10}$. 18 were excluded (crossover trials). Five studies ${ }^{19.23}$ were classified as 'awaiting classification studies' because their randomization was not clear, and we did not find the authors' contact details to request additional information. Contacts with the editors of the journals in which these papers were published were fruitless. Therefore, in the end, eight RCTs were included in this review. ${ }^{24}$.31 Figure 1 summarizes the study selection process. 

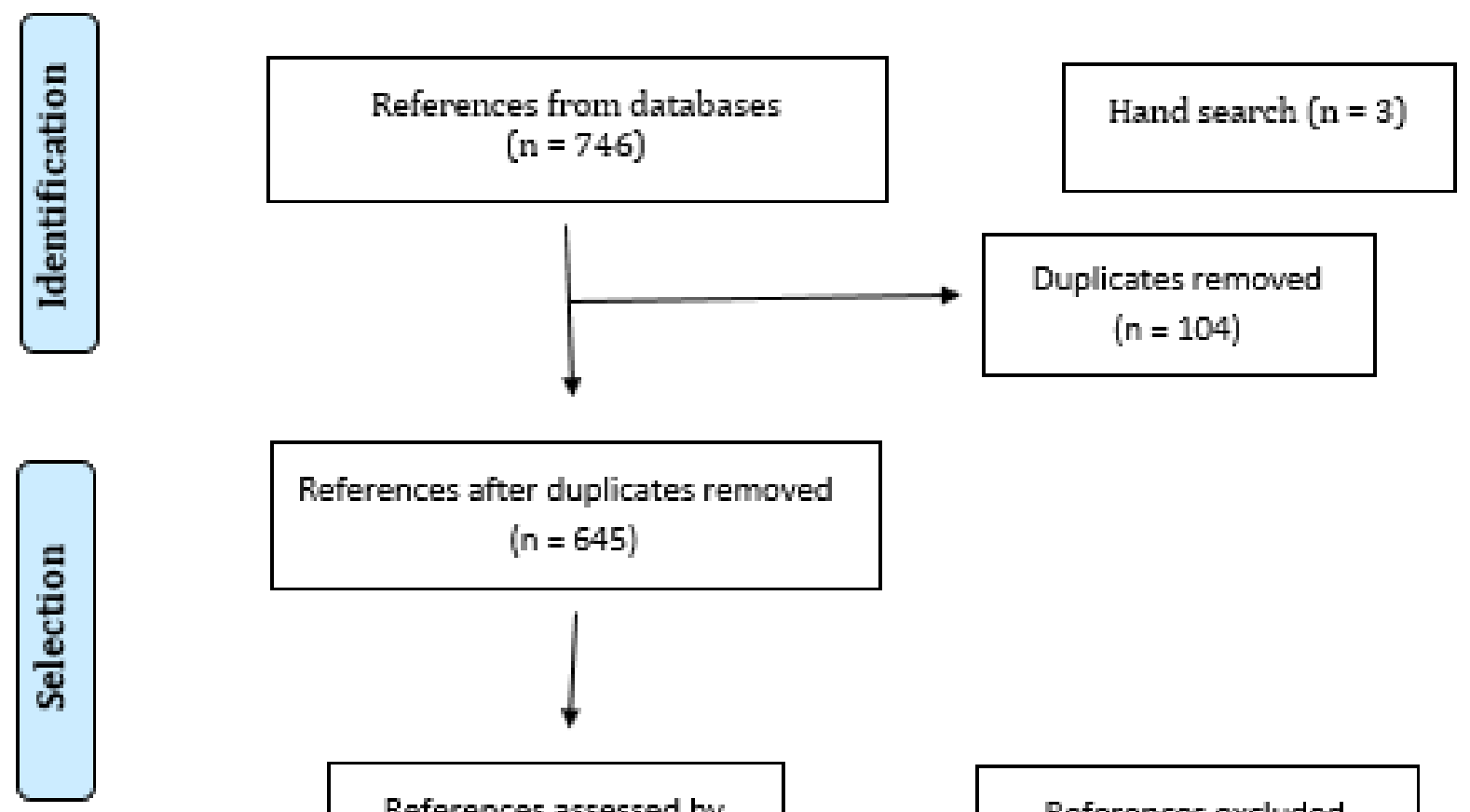
References after duplicates removed
( $n=645$ )
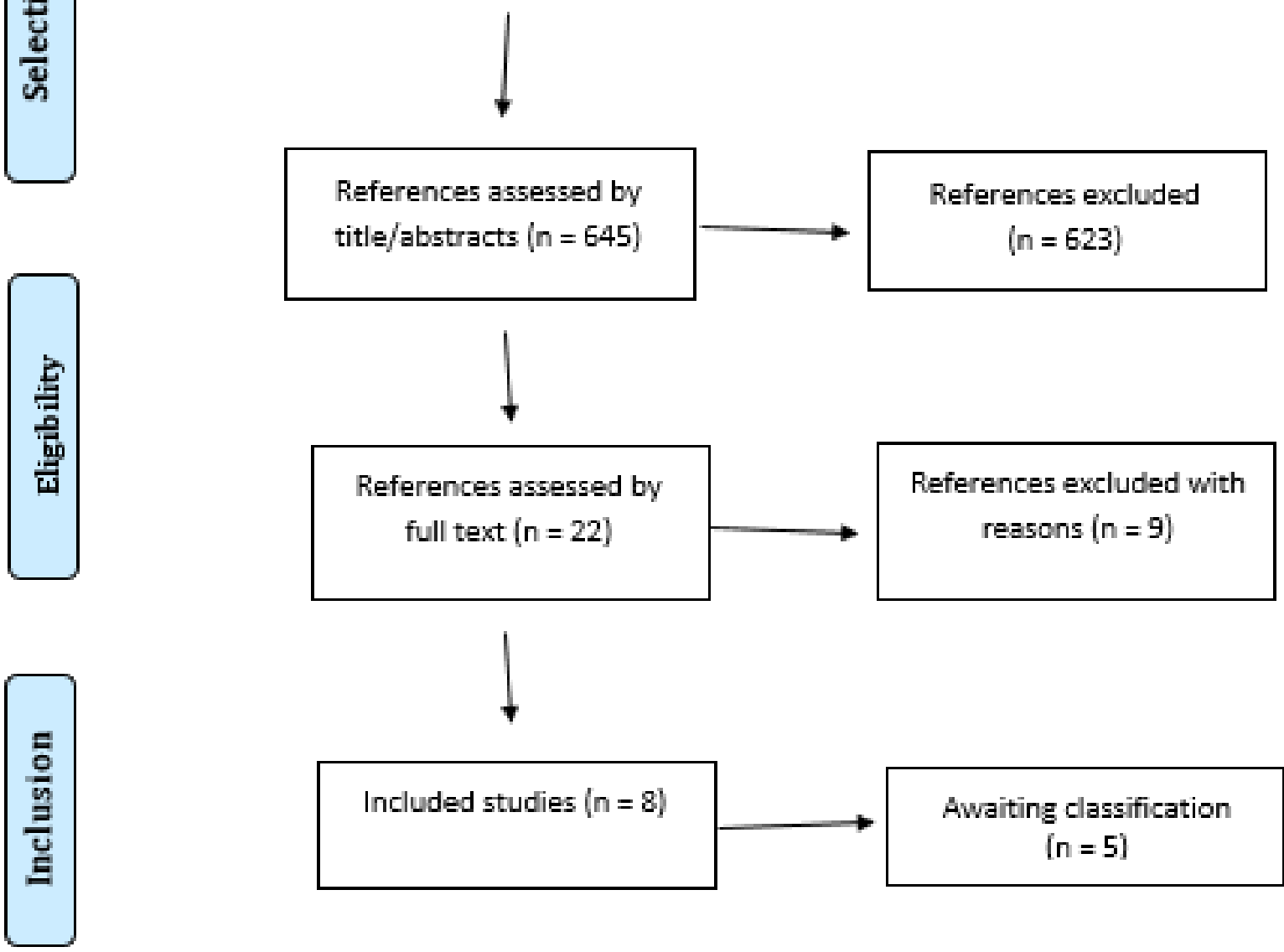

Figure 1. PRISMA flowchart. 


\section{Characteristics of the studies included}

Table 1 summarizes the main characteristics of the eight RCTs included.

Table 1. Main characteristics of the included studies.

\begin{tabular}{|c|c|c|c|c|c|c|c|}
\hline $\begin{array}{l}\text { Study, year, } \\
\text { country }\end{array}$ & $\begin{array}{l}\text { Study } \\
\text { design }\end{array}$ & Participants & Intervention & Comparator(s) & Outcomes of interest & $\begin{array}{l}\text { Time } \\
\text { points }\end{array}$ & $\begin{array}{l}\text { Funding } \\
\text { sources }\end{array}$ \\
\hline $\begin{array}{l}\text { Behan } 1985^{24} \\
\text { Scotland }\end{array}$ & RCT & $\begin{array}{l}\mathrm{n}=60 \\
\text { common migraine } \\
>2 \text { episodes/ month } \\
\text { mean } 30 \text { years } \\
\text { predominantly female (\% NR) }\end{array}$ & $\begin{array}{l}\text { Pizotifen } 1.5 \mathrm{mg} \\
\text { (once, at night) } \\
\text { ( } \mathrm{n}=30 \text { ) }\end{array}$ & $\begin{array}{l}\text { Clonidine } 25 u g \\
\text { twice/d } \\
(n=30)\end{array}$ & $\begin{array}{l}\text { * Number of episodes } \\
\text { * Duration of episodes } \\
\text { * Severity of episodes } \\
\text { * Adverse events (weight gain) }\end{array}$ & $2 \mathrm{mo}$ & NR \\
\hline $\begin{array}{l}\text { Behan } 1986^{25} \\
\text { Scotland }\end{array}$ & RCT & $\begin{array}{l}\mathrm{n}=67 \\
\text { common migraine (defined by } \\
\text { WFN) } \\
\text { frequent migraine episodes > } \\
2 \text { years } \\
\text { age NR } \\
82 \% \text { female }\end{array}$ & $\begin{array}{l}\text { Pizotifen } 0.5 \mathrm{mg} \\
\text { three times } / \mathrm{d} \\
(\mathrm{n}=35)\end{array}$ & $\begin{array}{l}\text { Naproxen } \\
\text { sodium } \\
550 \mathrm{mg} \text { twice } / \mathrm{d} \\
(\mathrm{n}=32)\end{array}$ & $\begin{array}{l}\text { * Number of episodes } \\
\text { * Duration } \\
\text { * Severity (excellent, moderate, mild, no } \\
\text { change or worse) } \\
\text { * Adverse events } \\
\text { (weight gain, nausea, vomiting) } \\
\text { * Analgesic medication required }\end{array}$ & $3 \mathrm{mo}$ & NR \\
\hline $\begin{array}{l}\text { Bellavance et } \\
\text { al., } 1990^{26} \\
\text { Canada }\end{array}$ & RCT & $\begin{array}{l}n=176 \\
\text { Common migraine (defined by } \\
\text { AHC), mean duration } 11.9 \text { years } \\
6.7 \text { episodes } / \text { month } \\
\text { mean } 32.5 \text { years } \\
79 \% \text { female }\end{array}$ & $\begin{array}{l}\text { Pizotifen } 0.5 \mathrm{mg} \\
\text { three times } / \mathrm{d}(0.5 \\
\mathrm{mg} \text { at bedtime and } \\
\text { gradually titrated } \\
\text { up over } 7 \mathrm{~d} \text { to } 0.5 \\
\mathrm{mg} \text { three times } / \mathrm{d}) \\
(\mathrm{n}=55)\end{array}$ & $\begin{array}{l}\text { Naproxen } \\
\text { sodium } 550 \mathrm{mg} \\
\text { twice } / \mathrm{d} \\
(\mathrm{n}=60) \\
\text { Placebo } \\
(\mathrm{n}=57)\end{array}$ & $\begin{array}{l}\text { * Frequency, duration and severity of } \\
\text { episodes (Headache Unit Index) } \\
\text { * Severity (rate of pain intensity, vomiting } \\
\text { episodes) } \\
\text { * Analgesic medication required } \\
\text { * Adverse events (weight gain, } \\
\text { gastrointestinal, skin effects) } \\
\text { * Patient's global assessment }\end{array}$ & $3 \mathrm{mo}$ & NR \\
\hline $\begin{array}{l}\text { Cerbo et al., } \\
1985^{27} \\
\text { Italy }\end{array}$ & RCT & $\begin{array}{l}n=30 \\
4 \text { to } 14 \text { episodes } / \text { month } \\
>6 \text { episodes, last } 6 \text { months } \\
\text { aged } 23 \text { to } 54 \text { years } \\
53.3 \% \text { male }\end{array}$ & $\begin{array}{l}\text { Pizotifen } 1.5 \mathrm{mg} \\
\text { nightly, for } 2 \mathrm{mon} \\
(\mathrm{n}=15)\end{array}$ & $\begin{array}{l}\text { Flunarizine } 15 \\
\text { mg nightly, for } 2 \\
\text { mo }(n=15)\end{array}$ & $\begin{array}{l}\text { * Number of episodes (per month) } \\
\text { * Duration (per month) } \\
\text { * Severity (total hours of intense pain } \\
\text { per month) } \\
\text { * Adverse events (weight gain, daytime } \\
\text { sedation) }\end{array}$ & 2 mo & NR \\
\hline $\begin{array}{l}\text { Chitsaz et al., } \\
2012^{28} \\
\text { Iran }\end{array}$ & RCT & $\begin{array}{l}\mathrm{n}=42 \\
\text { Common migraine (defined } \\
\text { by IHS) } \\
\text { frequent migraine episodes > } \\
1 \text { year } \\
4 \text { to } 14 \text { episodes/month, last } 3 \\
\text { months } \\
\text { aged } 23 \text { to } 54 \text { years } \\
57.1 \% \text { female }\end{array}$ & $\begin{array}{l}\text { Pizotifen } 0.5 \mathrm{mg} \\
\text { (bedtime) in the } \\
\text { first week; } 1.5 \\
\mathrm{mg} \text { (bedtime) in } \\
\text { the second and } \\
\text { subsequent weeks } \\
(\mathrm{n}=21)\end{array}$ & $\begin{array}{l}\text { Sodium } \\
\text { valproate } \\
200 \mathrm{mg} \text { twice } / \mathrm{d} \\
(\mathrm{n}=21)\end{array}$ & $\begin{array}{l}\text { * Number of episodes } \\
\text { * Duration } \\
\text { * Severity (VAS) } \\
\text { * Adverse events (weight gain, nausea, } \\
\text { vomiting) }\end{array}$ & $3 \mathrm{mo}$ & $\begin{array}{l}\text { Isfahan } \\
\text { University } \\
\text { of Medical } \\
\text { Sciences, } \\
\text { Iran }\end{array}$ \\
\hline $\begin{array}{l}\text { Lawrence et } \\
\text { al., } 197729 \\
\text { England }\end{array}$ & RCT & $\begin{array}{l}n=36 \\
\text { Common migraine (defined by } \\
\text { AHC), mean duration } 15.9 \text { years } \\
>4 \text { episodes/ month } \\
\text { mean age } 16-64 \text { years } \\
72.2 \% \text { female }\end{array}$ & $\begin{array}{l}\text { Pizotifen } 0.5 \mathrm{mg} \\
\text { once } / \mathrm{d} \text { (days } 1-2) \text {, } \\
\text { twice/d (days } 3-4) \text {, } \\
\text { three times (days } \\
5-15) \text {, two tablets, } \\
\text { three times } / \mathrm{d} \text { for } \\
10 \text { wks }(\mathrm{n}=14 \text { ) }\end{array}$ & $\begin{array}{l}\text { Placebo } \\
\text { same scheme } \\
(\mathrm{n}=14)\end{array}$ & $\begin{array}{l}\text { * Headache index (number of episodes } \\
\times \text { severity) } \\
{ }^{*} \text { Adverse events (weight gain) }\end{array}$ & $3 \mathrm{mo}$ & NR \\
\hline $\begin{array}{l}\text { Louis et al., } \\
1982^{30} \\
\text { Belgium and } \\
\text { Netherlands }\end{array}$ & RCT & $\begin{array}{l}n=75 \\
\text { Common migraine (defined by } \\
\text { AHC) } \\
>6 \text { episodes, last } 6 \text { months } \\
\text { mean age } 37 \text { years } \\
55 \% \text { female }\end{array}$ & $\begin{array}{l}\text { Pizotifen } 1 \mathrm{mg} \\
\text { nightly, and after } \\
5 \mathrm{~d} \text {, additional } \\
0.5 \mathrm{mg} \text { capsules } \\
\text { twice/d, for } 4 \mathrm{mo} \\
(\mathrm{n}=37)\end{array}$ & $\begin{array}{l}\text { Flunarizine } \\
10 \mathrm{mg} \text { nightly, } \\
\text { and after } 5 \\
\mathrm{~d} \text {, additional } \\
\text { placebo capsules } \\
\text { twice/d for } 4 \text { mo } \\
(\mathrm{n}=38)\end{array}$ & $\begin{array}{l}\text { * Number of episodes } \\
\text { * Duration } \\
\text { * Severity (4-point scale) } \\
\text { * Adverse events (weight gain, daytime } \\
\text { sedation) } \\
\text { * Patient's global assessment }\end{array}$ & $4 \mathrm{mo}$ & NR \\
\hline $\begin{array}{l}\text { Rascol et al., } \\
1986^{31} \\
\text { France }\end{array}$ & RCT & $\begin{array}{l}n=35 \\
\text { Common migraine (defined by } \\
\text { AHC), }>2 \text { years } \\
>6 \text { episodes, last } 6 \text { months } \\
\text { mean age } 38 \text { years } \\
71 \% \text { female }\end{array}$ & $\begin{array}{l}\text { Pizotifen } 0.73 \mathrm{mg} \\
\text { (days } 1-2), 1.46 \\
\mathrm{mg}(\text { days } 4-6) \text { and } \\
2.19 \mathrm{mg} \text { (days } \\
7.120), \text { for } 4 \mathrm{mo} \\
(\mathrm{n}=14)\end{array}$ & $\begin{array}{l}\text { Flunarizine } 10 \\
\mathrm{mg} / \mathrm{d} \text {, for } 4 \\
\text { months }(\mathrm{n}=21)\end{array}$ & $\begin{array}{l}\text { * Number of episodes } \\
\text { * Duration } \\
\text { * Severity (4-point scale) } \\
\text { * Adverse events (weight gain, changes } \\
\text { in blood pressure, hot flushes, drowsiness, } \\
\text { asthenia) } \\
\text { * Patient's global assessment }\end{array}$ & $4 \mathrm{mo}$ & NR \\
\hline
\end{tabular}

RCT: randomized clinical trial; n: number of participants; mg: milligrams; h: hours; NR: not reported; AHC: Ad Hoc Committee on Classification of Headache; d: days; mo: months; WFN: World Federation of Neurology Research Group on Migraine and Headache; IHS: International Headache Society; VAS: visual analogue scale. 


\section{Methodological quality assessment (risk of bias)}

Figure 2 summarizes the review authors' judgments on each risk-of-bias domain for each study included. The reasons for each judgment are summarized in the "Risk of bias" is detailed in Supplementary Material 2.

Regarding selection bias, only one study ${ }^{31}$ reported using an adequate method for generating the randomization sequence, and this study was judged as presenting a low risk of bias. In the other studies, insufficient information was provided, and these were classified as having an unclear risk of bias.

Regarding performance bias, three studies $24,25,28$ were classified as having high risk of bias because they were single-blinded. Only one study ${ }^{27}$ was considered as having a low risk of bias regarding blinding of participants, personnel and outcome assessors.

Four studies ${ }^{24-26,29}$ had substantial losses of participants during the study (16 to $44 \%$ ) and were classified as presenting high risk of attrition bias. Trial register protocols were not available for any of the studies included, leading to an overall unclear risk of reporting bias. Lastly, two studies $^{27,29}$ did not describe the baseline characteristics between groups and were judged as having unclear risk of other sources of bias.

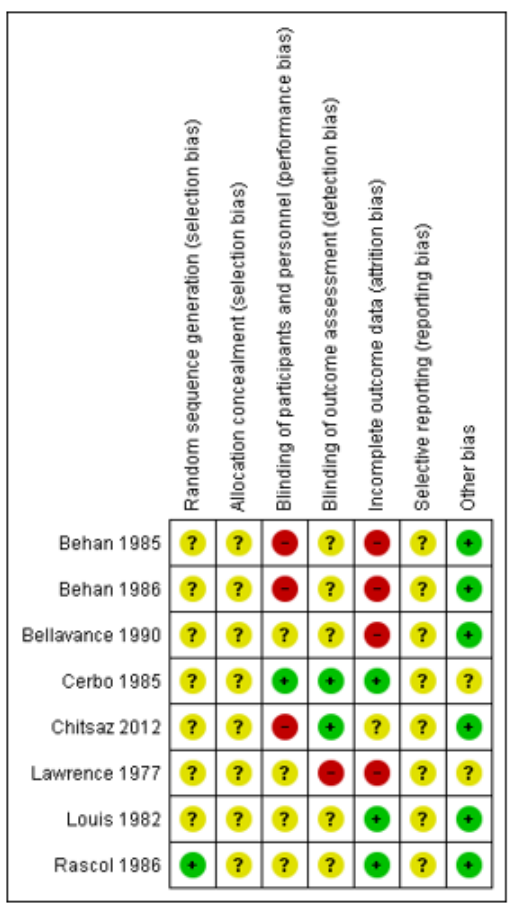

Figure 2. Risk-of-bias summary: review authors' judgments about each riskof-bias item for each study included.

\section{Effects of interventions}

\section{Comparison 1. Pizotifen versus placebo}

- Frequency, intensity and duration of episodes

Two studies ${ }^{26,29}$ evaluated these outcomes, and it was not feasible to pool their results in a meta-analysis due to their clinical diversity and the unavailability of data. When possible, estimated effects were calculated using individual study data.

Bellavance et al. ${ }^{26}$ (112 participants) assessed a headache unit index (sum of severity $x$ duration of each episode/number of treatment days) and reported that use of pizotifen led to improvement after three months of treatment, compared with placebo (mean of 3.27 versus 5.08 episodes per week). No difference was observed regarding pain intensity (mean 1.80 versus 1.86), severity of disability (mean 1.67 versus 1.77), duration of episodes (mean 1.59 versus 1.55), use of migraine rescue medication per week (mean 0.82 versus 1.26) and vomiting episodes per week (mean 0.08 versus 0.48 ).

Lawrence et al. (1977) ${ }^{29}$ (36 participants) assessed a weekly headache index by multiplying the number of episodes by their intensity, according to the following scale: severe $=3$, moderate $=2$ and mild $=1$. In the pizotifen group, $85.7 \%(12 / 14)$ achieved complete resolution of symptoms or progressive improvement after three months of treatment, compared with $14.2 \%(2 / 14)$ reporting slight improvement in the placebo group. Pizotifen seemed to improve compared with placebo, but this result was considered very imprecise due to the wide confidence interval (RR 6.00; $95 \% \mathrm{Cl} 1.63$ to $22.03 ; p=$ 0.007).

\section{- Adverse events}

The meta-analysis results showed no difference between pizotifen and placebo regarding weight gain (ranging from 0.5 to $4 \mathrm{~kg}$ ) after three months of treatment. However, an imprecision in this estimated effect was observed due to the wide confidence interval (RR 1.92; $95 \% \mathrm{Cl}$ 0.30 to 12.38 ; 2 RCTs; 142 participants; $1^{2}=67 \% ; p=$ 0.49) (Figure 3). Moreover, there was a slight statistical heterogeneity (67\%), which can be explained as possible clinical differences between participants, including in the treatment scheme with pizotifen. 


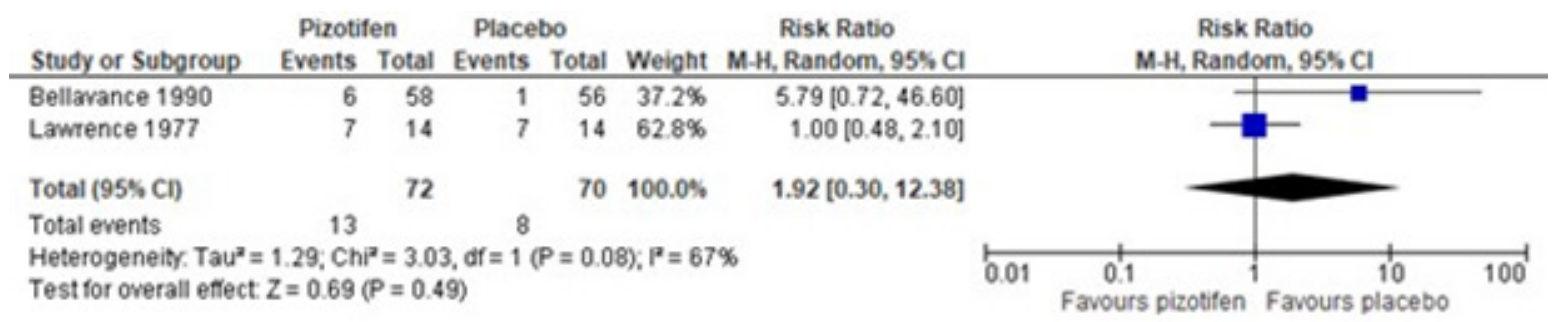

Figure 3. Meta-analysis of pizotifen versus placebo. Outcome: adverse events (weight gain).

Bellavance et al. (1990) ${ }^{26}$ also presented a non-significant difference between their groups regarding the following adverse events: gastrointestinal $(7 / 58$ versus $3 / 56)$; skin $(0 / 58$ versus $1 / 56)$, and other $(2 / 58$ versus $4 / 56)$. The adverse events informed by patients were generally of mild or moderate intensity.

\section{- Patients' overall evaluation}

In one study ${ }^{26}$, good or excellent ratings in the patients' overall evaluation were reported by $68 \%$ of pizotifen-treated participants and $36 \%$ of placebo-treated participants ( $p=$ 0.005).

Comparison 2: Pizotifen versus flunarizine

- Frequency, intensity and duration of episodes
Regarding the severity of episodes measured on a pain intensity scale, in one study ${ }^{27}$ an improvement of $81 \%$ in the flunarizine group was observed, compared with $40 \%$ in the pizotifen group $(p<0.01)$. The episodes' duration was not significantly changed by either pizotifen or flunarizine (mean 8.5 versus 31 , respectively). Louis et al. ${ }^{30}$ used a 4-point scale to assess the severity of the episodes, and no difference was noted between pizotifen and flunarizine, considering the number of participants with migraine grade 1 (mild) after four months of treatment (RR 0.14; $95 \% \mathrm{Cl} 0.02$ to $1.06 ; \mathrm{p}=0.06$ ). This effect was uncertain, given the breadth of the confidence interval. These authors also stated that the episodes' duration was not changed by either drug (no numerical data provided).

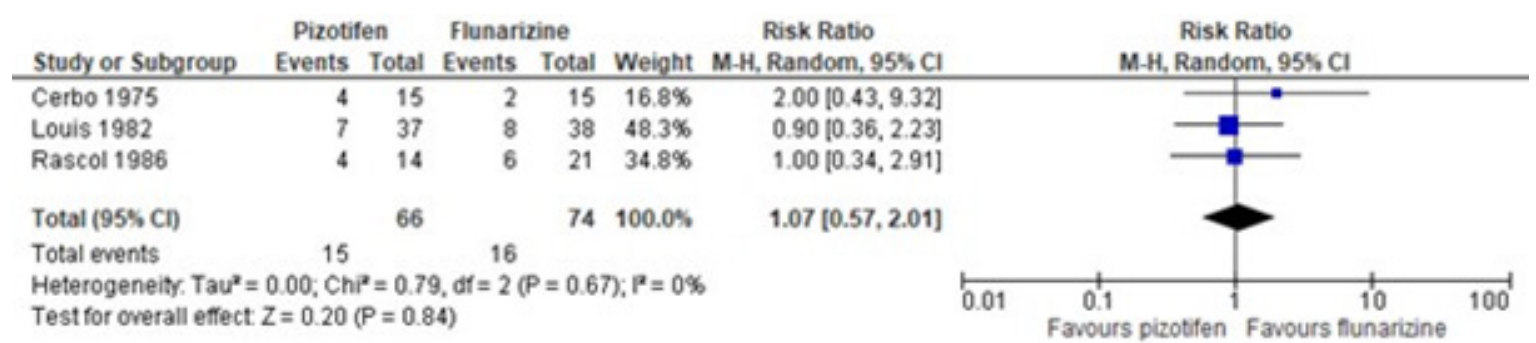

Figure 4. Meta-analysis of pizotifen versus flunarizine. Outcome: adverse events (weight gain).

Three studies $27,30,31$ assessed these outcomes, but it was not possible to group their data in a meta-analysis or calculate the estimated effects for most individual studies due to missing numerical data.

One study ${ }^{31}$ (75 participants) presented a mean reduction in the number of migraine episodes of $54 \%$ for the flunarizine group and $45 \%$ for the pizotifen group after four months. The authors stated that there was a significant difference between the groups $(p<0.001)$. Cerbo et al. ${ }^{27}$ (30 participants) reported that there was no difference between drug treatments regarding the mean reduction in the number of episodes per month (mean 2.67 pizotifen versus 3.56 flunarizine). Rascol et al. ${ }^{31}$ (35 participants) reported that the reduction in the flunarizine group (65\%) was slightly greater than in the pizotifen group (45\%), but the intergroup difference was not significant after two months of treatment $(p=0.10)$.

\section{Adverse events}

Weight gain was reported in the three studies comparing pizotifen with flunarizine ${ }^{27,30,31}$, ranging from 4 to $11 \mathrm{~kg}$. The results from a meta-analysis showed that there was no difference between the groups ( $\mathrm{RR} 1.07 ; 95 \% \mathrm{Cl} 0.57$ to $2.01 ; 3$ RCTs; 140 participants; $I^{2}=0 \% ; p=0.84$ ) (Figure $4)$.

In two studies 27,30 , daytime sedation among the participants in both groups was reported. The results from a metaanalysis showed no difference between groups (RR 0.49; $95 \% \mathrm{Cl} 0.24$ to 1.01 ; 2 RCTs; 105 participants; $\left.\right|^{2}=0 \%$; $\mathrm{p}=0.48)$. Rascol et al. ${ }^{31}$ found no difference between the groups regarding occurrences of other adverse events, including changes in blood pressure, hot flushes, drowsiness and severe asthenia $(1 / 14$ versus $2 / 15$; RR $2.00 ; 95 \% \mathrm{Cl} 0.20$ to $19.78 ; \mathrm{p}=0.55)$. However, both effect estimates had wide confidence intervals and were 
highly imprecise.

\section{Patients' overall evaluation}

The participants in two studies 30,31 reported that the effects from both treatments were positive, but there was no significant difference between the groups after 4 months of treatment (RR 0.90; $95 \% \mathrm{Cl} 0.61$ to $1.32 ; 2 \mathrm{RCTs} ; 12=$ $0 \% ; 101$ participants; $p=0.40$ ) (Figure 5).
The pooled results from two studies ${ }^{26,27}$ showed that subjects who received naproxen presented less weight gain than those who received pizotifen. However, this meta-analysis was very imprecise (RR $11.45 ; 95 \% \mathrm{Cl} 1.52$ to $86.21 ; 2$ RCTs; $12=0 \% ; 183$ participants; $p=0.90$ ) (Figure 6).

In two studies ${ }^{26,27}$, other adverse events relating to the treatments were reported. These included nausea,

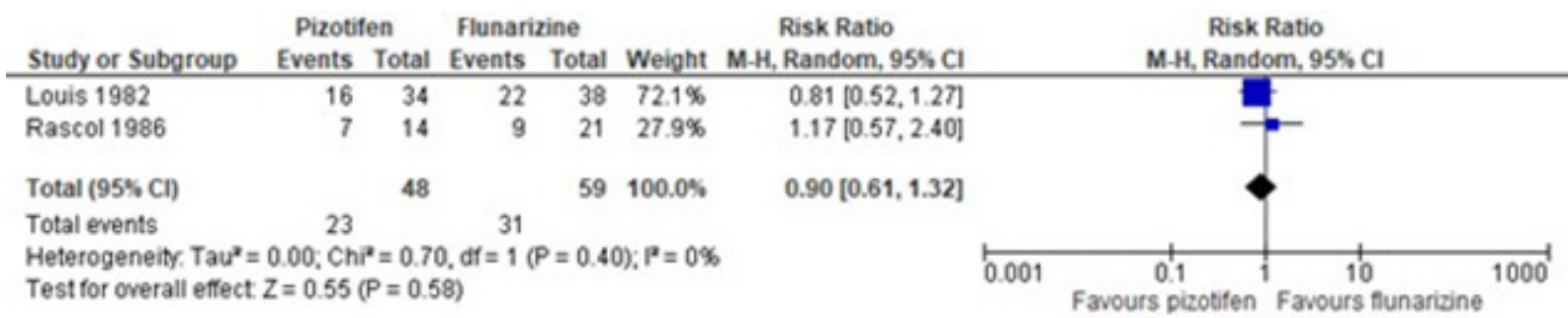

Figure 5. Meta-analysis on pizotifen versus flunarizine. Outcome: patients' overall evaluation.

Comparison 3: Pizotifen versus naproxen

- Frequency, intensity and duration of episodes

Two studies ${ }^{25,26}$ assessed these outcomes, but it was not possible to group their data in a meta-analysis because the outcomes were measured using different methods. In one study 25 (67 participants), no significant differences between the groups were found regarding frequency (MD $-0.10 ; 95 \% \mathrm{Cl}-0.68$ to 0.48 ) or severity of episodes (MD $-0.20 ; 95 \% \mathrm{Cl}-0.93$ to 0.53$)$, after 3 months of treatment. There were no significant differences between the groups regarding the duration of attacks or use of rescue medication (no numerical data provided).

In another study ${ }^{27}$ (115 participants), a headache unit index (sum of severity and duration of each episode/ number of treatment days) was assessed, and no difference was found between the groups after three months (mean of 3.27 versus 2.85 episodes per week). There were also no differences regarding pain intensity (mean 1.80 versus 1.64 ), severity of disability (mean 1.67 versus 1.58), duration of episodes (mean 1.59 versus 1.35), migraine rescue medication per week (mean 0.82 versus 0.73 ) or vomiting episodes per week (mean 0.08 versus 0.25 ).

\section{- Adverse events}

\begin{tabular}{|c|c|c|c|c|c|c|}
\hline \multirow[b]{2}{*}{ Study or Subgroup } & \multicolumn{2}{|c|}{ Pizotifen } & \multicolumn{2}{|c|}{ Naproxen } & \multirow[b]{2}{*}{ Weight } & \multirow{2}{*}{$\begin{array}{c}\text { Risk Ratio } \\
\text { M.H, Random, } 95 \% \text { C }\end{array}$} \\
\hline & Events & Total & Events & Total & & \\
\hline Behan 1986 & 5 & 35 & 0 & 32 & $50.0 \%$ & $10.08[0.58,175.41]$ \\
\hline Bellavance 1990 & 6 & 58 & 0 & 58 & $50.0 \%$ & $13.00[0.75,225.5$ \\
\hline Total $(95 \%$ CD) & & 93 & & 90 & $100.0 \%$ & $11.45[1.52,86$. \\
\hline Total events & 11 & & 0 & & & \\
\hline
\end{tabular}

Figure 6. Meta-analysis on pizotifen versus naproxen. Outcome: adverse events (weight gain) vomiting and gastrointestinal effects. However, there were no differences between the groups observed.

\section{Comparison 4: Pizotifen versus sodium valproate}

- Frequency, intensity and duration of episodes

One study ${ }^{28}$ (60 participants) assessed this comparison. Significant mean reductions in the frequency (MD 2.80; $95 \% \mathrm{Cl} 1.42$ to 4.18 ) and severity (RR 1.30; $95 \% \mathrm{Cl}$ 0.61 to 1.99 ) of headaches were observed in the pizotifen group, compared with the sodium valproate group, at the end of three months. No difference in reducing headache duration was found (RR 1.10; $95 \% \mathrm{Cl}-1.94$ to 4.14 ).

\section{- Adverse events}

Regarding safety, 30 participants presented one or more adverse events during the study ${ }^{28}: 18$ in the pizotifen group and 12 in the sodium valproate group. No difference in weight gain was observed (RR 0.33; 95\% Cl 0.04 to 2.95). Sedation, nausea, and increased appetite were the other adverse events observed after three months of treatment, but no difference was noted between groups.

\section{Comparison 5: Pizotifen versus clonidine}

- Frequency, intensity and duration of episodes

One study ${ }^{24}$ (60 participants) assessed this comparison
Risk Ratio M.H, Random, 95\% Cl

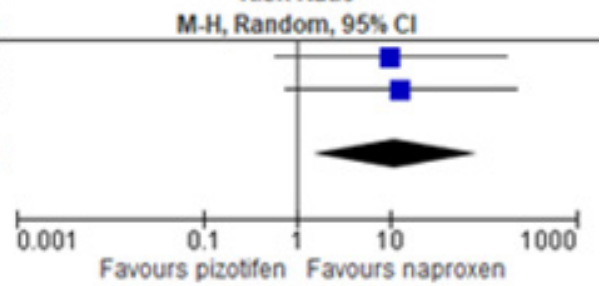


and showed an overall greater improvement through use of pizotifen than clonidine. After two months of treatment, the authors reported that approximately $50 \%$ of the participants who received pizotifen $(6 / 14)$ had no headaches, whereas only one participant who received clonidine was completely headache-free (1/19). There were overall reductions in the pizotifen group regarding frequency, severity and duration of episodes and the number of associated symptoms in most patients (RR 5.88; $95 \% \mathrm{Cl} 2.06$ to $16.78 ; \mathrm{p}=0.0002$ ).

\section{- Adverse events}

The participants in the study by Behan et al. ${ }^{24}$ presented weight gains. However, no numerical data were provided, and the authors reported that only in one case, was it sufficient to cause the patient's withdrawal from the study. No adverse events were seen in the clonidine group.

\section{Certainty of the evidence}

Based on the GRADE approach, the certainty the evidence regarding pizotifen versus placebo was classified as 'very low'. It indicated that we had little confidence in the effect estimate. The evidence was downgraded due to methodological limitations, inconsistency (substantial heterogeneity between studies) and imprecision (wide confidence intervals and small sample size). The findings are summarized in a table of assessment details, which is presented as Supplementary Material 3.

\section{Discussion}

Migraine is a burden for patients and society. The socioeconomic costs of migraine are immense ${ }^{32}$, with average direct costs of $€ 2427 /$ patient/year in the USA and Canada $^{33}$ and $€ 1222$ to $€ 1482 /$ patient/year in Europe. ${ }^{34,35}$ These societies will invest in newer drugs and will reimburse the costs of anti-CGRP MAbs so that migraineurs will have lower financial burdens and less absenteeism and presenteeism. The same cannot be said for developing countries, where treating migraine at the cost of circa $€ 1600 /$ patient/year is unrealistic. Poorer countries require efficient but inexpensive drugs that provide effective migraine treatments. For this situation, pizotifen may be an alternative. This systematic review has shown that pizotifen is superior to placebo and not inferior to naproxen, flunarizine, valproate or clonidine. The ensuing weight gain is not tolerated by all patients ${ }^{36}$, but it may be acceptable in some cases and situations. An additional benefit of pizotifen is a very safe profile in pregnancy cases (category B in the Food and Drug Administration
- FDA). All other prophylactic migraine treatments are at least category $\mathrm{C}$ by the FDA. ${ }^{37}$

The adverse events reported in pizotifen trials are essentially restricted to weight gain. The profile of adverse events of most prophylactic drugs for migraine leads to high rates of discontinuation. ${ }^{38}$ Even for erunumab, an anti-CGRP MAb, the discontinuation rate over six months was $27.7 \%$ in real life. ${ }^{39}$

Trials on pizotifen were conducted decades ago, with low numbers of participants and unclear risks of bias. The patients with migraine included in most pizotifen studies were not selected to take the International Headache Society criteria into consideration criteria. ${ }^{40}$ It is unlikely that an inexpensive drug-like pizotifen will be tested in modern trials. In an ideal scenario, a new trial should compare pizotifen's efficacy and safety compared to another drug.

Despite the limitations mentioned above, we believe that these meta-analyses' results are sufficient for pizotifen to be considered in treatments for migraine for patients who are not preoccupied with weight gain.

\section{Conclusion}

Pizotifen was superior to placebo and not inferior to naproxen, flunarizine, valproate or clonidine, for treating migraine. The adverse events from the use of pizotifen were restricted to weight gain. The clinical trials on pizotifen are now a few decades old, and the body of evidence was classified as 'very low' due to methodological limitations. A new trial in the $21^{\text {st }}$ century could render good evidence for this inexpensive drug's safety and efficacy.

\section{Funding: none.}

Conflicts of interest/competing interests: none.

Authors contribution: all authors contributed to the study concept and design and participated in searching and selecting articles. ALCM, carried out meta-analyses; YDF, paper draft and final version.

Yara Dadalti Fragoso

https://orcid.org/0000-0001-8726-089X

Giullia C. Mangas Lopes

https://orcid.org/0000-0002-3223-9871

Giovanna Marcilio Santos

https://orcid.org/0000-0002-7195-339X

Paula Carturan

https://orcid.org/0000-0002-1533-2206

Ana Luiza C. Martimbianco

https://orcid.org/0000-0002-4361-4526 


\section{References}

1. Woldeamanuel YW and Cowan RP. Migraine affects 1 in 10 people worldwide featuring recent rise: A systematic review and meta-analysis of communitybased studies involving 6 million participants. I Neurol Sci 2017;372:307-315 Doi:10.1016/i. jns.2016.11.071

2. Leonardi $M$ and Raggi A. A narrative review on the burden of migraine: when the burden is the impact on people's life. J Headache Pain 2019;20(1):41 Doi:10.1186/s10194-019-0993-0

3. Silberstein SD, Lee L, Gandhi K, Fitzgerald T, Bell J and Cohen JM. Health care Resource Utilization and Migraine Disability Along the Migraine Continuum Among Patients Treated for Migraine. Headache 2018;58(10):1579-1592 Doi:10.1111/head. 13421

4. Kokoti L, Drellia K, Papadopoulos D and Mitsikostas DD. Placebo and nocebo phenomena in anti- CGRP monoclonal antibody trials for migraine prevention: a meta-analysis. J Neurol 2020;267(4):1158-1170 Doi:10.1007/s00415-019-09673-7

5. Higgins JPT TJ, Chandler J, Cumpston M, et al. Cochrane Handbook for Systematic Reviews of Interventions version 6.0. [Internet]. 2019. Available from: www. training.cochrane.org/handbook.

6. Moher D, Liberati A, Tetzlaff J and Altman DG. Preferred reporting items for systematic reviews and meta-analyses: the PRISMA statement. J Clin Epidemiol 2009;62(10):1006-1012 Doi:10.1016/i. jclinepi.2009.06.005

7. Ouzzani M, Hammady $H$, Fedorowicz $Z$ and Elmagarmid A. Rayyan-a web and mobile app for systematic reviews. Systematic Reviews 2016;5(1):210 Doi:10.1186/s13643-016-0384-4

8. Higgins JPT, Thompson SG, Deeks JJ and Altman DG. Measuring inconsistency in meta-analyses. BMJ 2003;327(7414):557-560 Doi:10.1136/ bmi.327.7414.557

9. Guyatt $G H$, Oxman $A D$, Vist GE, Kunz R, FalckYtter $Y$, Alonso-Coello $P$ and Schünemann $H J$. GRADE: an emerging consensus on rating quality of evidence and strength of recommendations. Bmi 2008;336(7650):924-926 Doi:10.1136/ bmi.39489.470347.AD

10. Ryan RE. BC-105 a new preparation for the interval treatment of migraine--a double blind evaluation compared with a placebo. Headache 1971;11(1):618 Doi:10.1111/j.1526-4610.1971.hed1 10106.x

11. Starý O, Janský $M$, Figar $S$ and Stein J. Clinical physiological study of the action of BC 105 (Sandoz,
Basle) in the interval therapy of migraine. Eur Neurol 1974; 1 1(6):353-362 Doi:10.1159/000114334

12. Vilming S, Standnes B and Hedman C. Metoprolol and pizotifen in the prophylactic treatment of classical and common migraine. A double-blind investigation. Cephalalgia 1985;5(1):17-23 Doi:10.1046/i.14682982.1985.0501017.x

13. Kangasniemi P. Placebo, 1-isopropylnoradrenochrome5-monosemicarbazono and pizotifen in migraine prophylaxis. Headache 1979;19(4):219-222 Doi:10.1111/j.1526-4610.1979.hed1904219.x

14. Lance JW, Anthony M and Somerville B. Comparative trial of serotonin antagonists in the management of migraine. $\mathrm{Br}$ Med J 1970;2(5705):327-330 Doi: $10.1136 / \mathrm{bmi} .2 .5705 .327$

15. Hübbe P. The prophylactic treatment of migraine with an antiserotonin pizotifen. Acta Neurol Scand 1973;49(1):108-114 Doi: $10.1111 /$ j. 1600-0404.1973.tb01282.x

16. Havanka-Kanniainen H, Hokkanen E and Myllylä WV. Efficacy of nimodipine in comparison with pizotifen in the prophylaxis of migraine. Cephalalgia 1987;7(1):713 Doi:10.1046/i.1468-2982.1987.0701007.x

17. Dalsgaard-Nielsen $T$ and Ulrich J. Long-term effect and tolerance during prophylactic treatment of migraine with a benzo-cycloheptathiophene derivative, pizotifen. Headache 1973;13(1):12-18 Doi:10.1111/j.1526-4610.1973.hed1301012.x

18. Carroll JD and Maclay WP. Pizotifen (BC 105) in migraine prophylaxis. Curr Med Res Opin 1975;3(2):68-71 Doi: 10.1185/03007997509113649

19. Andersson PG. BC-105 and deseril in migraine prophylaxis (A double-blind study). Headache 1973;13(2):71-73 Doi:10.1111/j.1526-4610.1973. hed1302068.x

20. Arthur GP and Hornabrook RW. The treatment of migraine with BC 105 (pizotifen): a double blind trial. N Z Med J 1971;73(464):5-9

21. Bademosi $\bigcirc$ and Osuntokun BO. Pizotifen in the management of migraine. Practitioner 1978;220(1316):325-327

22. Barolin GS. Long-term therapy of persistent migraine with BC-105. Z Allgemeinmed 1970;46(22):11301133

23. Behan PO. Pizotifen in the treatment of severe recurrent headache single and divided dose therapy compared. Br J Clin Pract 1982;36(1):13-17

24. Behan PO. Prophylactic Treatments for Migraine - A Comparison of Pizotifen and Clonidine. Cephalalgia 1985;5(3 suppl):524-525 Doi:10.1177/03331024850050S3206

25. Behan P, Connelly K and Pain F. Prophylaxis of 
migraine: a comparison between naproxen sodium and pizotifen. Headache 1986;26(5):237-239 Doi:10.1111/i.1526-4610.1986.hed2605237.x

26. Bellavance AJ and Meloche JP. A comparative study of naproxen sodium, pizotyline and placebo in migraine prophylaxis. Headache 1990;30(11):710-715 Doi: $10.1111 /$ i.1526-4610.1990.hed3011710.x

27. Cerbo R, Casacchia M, Formisano R, Buzzi MG, Boni $B$, Feliciani $M, \ldots$ Agnoli A. Double-blind clinical study: flunarizine versus pizotifen in a single nightly dose in hemicrania patients. Riv Neurol 1985;55(2):139-146

28. Chitsaz A, Najafi MR, Zangeneh FA, Norouzi R, Mehri Salari M. Pizotifen in migraine prevention: A comparison with sodium valproate. Neurology Asia 2012;17(4):319-24.

29. Lawrence ER, Hossain M and Littlestone W. Sanomigran for migraine prophylaxis, controlled multicenter trial in general practice. Headache 1977; 17(3):109-112 Doi:10.1111/j.1526-4610.1977.hed1703109.x

30. Louis $\mathrm{P}$ and Spierings EL. Comparison of flunarizine (Sibelium) and pizotifen (Sandomigran) in migraine treatment: a double-blind study. Cephalalgia 1982;2(4): 197-203 Doi:10.1046/j.1468 2982.1982.0204197.x

31. Rascol A, Montastruc JL and Rascol O. Flunarizine versus pizotifen: a double-blind study in the prophylaxis of migraine. Headache 1986;26(2):8385 Doi:10.1111/i.1526-4610.1986.hed2602083.x

32. Mennini FS, Gitto L and Martelletti P. Improving care through health economics analyses: cost of illness and headache. J Headache Pain 2008;9(4):199-206 Doi:10.1007/s10194-008-0051-9

33. Stokes M, Becker WJ, Lipton RB, Sullivan SD, Wilcox TK, Wells L, . . . Blumenfeld AM. Cost of health care among patients with chronic and episodic migraine in Canada and the USA: results from the International Burden of
Migraine Study (IBMS). Headache 2011;51(7): 10581077 Doi:10.1111/j.1526-4610.2011.01945.x

34. Negro A, Sciattella P, Rossi D, Guglielmetti $M$, Martelletti $P$ and Mennini FS. Cost of chronic and episodic migraine patients in continuous treatment for two years in a tertiary level headache Centre. J Headache Pain 2019;20(1):120 Doi:10.1186/ s10194-019-1068-y

35. Linde M, Gustavsson A, Stovner LJ, Steiner TJ, Barré J, Katsarava Z, . . Andrée C. The cost of headache disorders in Europe: the Eurolight project. Eur J Neurol 2012;19(5):703-711 Doi:10.1111/j.1468$1331.2011 .03612 . x$

36. Mansfield C, Gebben DJ, Sutphin J, Tepper SJ, Schwedt TJ, Sapra S and Shah N. Patient Preferences for Preventive Migraine Treatments: A DiscreteChoice Experiment. Headache 2019;59(5):715-726 Doi: 10.1111 /head. 13498

37. Johnson $\mathrm{CH}$, Morgan $\mathrm{M}, \mathrm{O}^{\prime}$ Bryan $\mathrm{S}$, Patel H and Smiley J. Drugs in Pregnancy. [Internet]. 2008. Available from: https://ifmo.cchs.ua.edu/files/2013/09/ Drugs_Pregnancy.pdf

38. Vo P, Wen S, Martel MJ, Mitsikostas D, Reuter U and Klatt J. Benefit-risk assessment of erenumab and current migraine prophylactic treatments using the likelihood of being helped or harmed. Cephalalgia 2019;39(5):608616 Doi:10.1177/0333102418801579

39. Robblee J, Devick KL, Mendez N, Potter J, Slonaker J and Starling AJ. Real-World Patient Experience With Erenumab for the Preventive Treatment of Migraine. Headache 2020;60(9):2014-2025 Doi:10.1111/ head. 13951

40. Internacional Headache Society. Headache Classification Committee of the International Headache Society (IHS) The International Classification of Headache Disorders, 3rd edition. Cephalalgia 2018;38(1):1211 Doi:10.1177/0333102417738202 
Supplementary material 1. Search strategy for each electronic database (on 20 July 2020 and updated on 18 February 2021 ).

\begin{tabular}{|c|c|}
\hline $\begin{array}{c}\text { MEDLINE } \\
\text { (via Pubmed) }\end{array}$ & $\begin{array}{l}\text { \#1 "Migraine Disorders"[Mesh] OR (Disorder, Migraine) OR (Disorders, Migraine) OR (Migraine Disorder) OR Migraine OR } \\
\text { Migraines OR (Migraine Headache) OR (Headache, Migraine) OR (Headaches, Migraine) OR (Migraine Headaches) OR } \\
\text { (Acute Confusional Migraine) OR (Acute Confusional Migraines) OR (Migraine, Acute Confusional) OR (Migraines, Acute } \\
\text { Confusional) OR (Status Migrainosus) OR (Hemicrania Migraine) OR (Hemicrania Migraines) OR (Migraine, Hemicrania) OR } \\
\text { (Migraines, Hemicrania) OR (Migraine Variant) OR (Migraine Variants) OR (Variant, Migraine) OR (Variants, Migraine) OR } \\
\text { (Sick Headache) OR (Headache, Sick) OR (Headaches, Sick) OR (Sick Headaches) OR (Abdominal Migraine) OR (Abdominal } \\
\text { Migraines) OR (Migraine, Abdominal) OR (Migraines, Abdominal) OR (Cervical Migraine Syndrome) OR (Cervical Migraine } \\
\text { Syndromes) OR (Migraine Syndrome, Cervical) OR (Migraine Syndromes, Cervical) } \\
\text { \#2 "Migraine with Aura"[Mesh] OR (Migraine with Auras) OR (Familial Hemiplegic Migraine) OR (Familial Hemiplegic } \\
\text { Migraines) OR (Hemiplegic-Ophthalmoplegic Migraine) OR (Hemiplegic Migraine, Familial) OR (Migraine with Typical } \\
\text { Aura) OR (Classical Migraine) OR (Migraine, Classical) OR (Migraine, Classic) OR (Classic Migraine) OR (Migraine with } \\
\text { Acute Onset Aura) OR (Acute Onset Aura Migraine) OR (Migraine with Prolonged Aura) OR (Migraine, Prolonged Aura) OR } \\
\text { (Prolonged Aura Migraine) OR (Complicated Migraine) OR (Migraine, Complicated) OR (Basilar-Type Migraine) OR (Basilar } \\
\text { Type Migraine) OR (Migraine, Basilar-Type) OR (Basilar Migraine) OR (Basilar Migraines) OR (Migraine, Basilar) OR (Basilar } \\
\text { Artery Migraine) OR (Migraine, Basilar Artery) OR (Migraine Aura without Headache) OR (Typical Aura without Headache) } \\
\text { \#3 "Migraine without Aura"[Mesh] OR (Common Migraine) OR (Common Migraines) OR (Migraines, Common) OR (Migraine, } \\
\text { Common) } \\
\text { \#4 \#1 OR \#2 OR \#3 } \\
\text { \#5 "Pizotyline"[Mesh] OR Pizotifen OR Polomigran OR Sandomigran OR (BC-105) OR (BC 105) OR (BC105) } \\
\text { \#6 \#3 AND \#4 (236) }\end{array}$ \\
\hline $\begin{array}{c}\text { Embase } \\
\text { (via Elsevier) }\end{array}$ & $\begin{array}{l}\text { \#1 'migraine'/exp OR 'Disorder, Migraine' OR 'Disorders, Migraine' OR 'Migraine Disorder' OR Migraine OR Migraines OR } \\
\text { 'Migraine Headache' OR 'Headache, Migraine' OR 'Headaches, Migraine' OR 'Migraine Headaches' OR 'Acute Confusional } \\
\text { Migraine' OR 'Acute Confusional Migraines' OR 'Migraine, Acute Confusional' OR 'Migraines, Acute Confusional' OR 'Status } \\
\text { Migrainosus' OR 'Hemicrania Migraine' OR 'Hemicrania Migraines' OR 'Migraine, Hemicrania' OR 'Migraines, Hemicrania' } \\
\text { OR 'Migraine Variant' OR 'Migraine Variants' OR 'Variant, Migraine' OR 'Variants, Migraine' OR 'Sick Headache' OR } \\
\text { 'Headache, Sick' OR 'Headaches, Sick' OR 'Sick Headaches' OR 'Abdominal Migraine' OR 'Abdominal Migraines' OR } \\
\text { 'Migraine, Abdominal' OR 'Migraines, Abdominal' OR 'Cervical Migraine Syndrome' OR 'Cervical Migraine Syndromes' OR } \\
\text { 'Migraine Syndrome, Cervical' OR 'Migraine Syndromes, Cervical' } \\
\text { \#2 'migraine with aura'/exp OR 'migraine without aura'/exp } \\
\text { \#3 \# } 1 \text { OR \#2 } \\
\text { \#4 'pizotifen'/exp OR pizotyline OR polomigran OR sandomigran OR 'bc 105' OR bc105 } \\
\text { \#5 \#3 AND \#4 } \\
\text { \#5 AND [embase]/lim NOT ([embase]/lim AND [medline]/lim) (469) }\end{array}$ \\
\hline $\begin{array}{l}\text { Cochrane Central } \\
\text { Register of Controlled } \\
\text { Trials (CENTRAL) }\end{array}$ & $\begin{array}{l}\text { \#1 MeSH descriptor: [Migraine Disorders] explode all trees } \\
\text { \#2 "Disorder, Migraine" OR "Disorders, Migraine" OR "Migraine Disorder" OR Migraine OR Migraines OR "Migraine } \\
\text { Headache" OR "Headache, Migraine" OR "Headaches, Migraine" OR "Migraine Headaches" OR "Acute Confusional } \\
\text { Migraine" OR "Acute Confusional Migraines" OR "Migraine, Acute Confusional" OR "Migraines, Acute Confusional" OR } \\
\text { "Status Migrainosus" OR "Hemicrania Migraine" OR "Hemicrania Migraines" OR "Migraine, Hemicrania" OR "Migraines, } \\
\text { Hemicrania" OR "Migraine Variant" OR "Migraine Variants" OR "Variant, Migraine" OR "Variants, Migraine" OR "Sick } \\
\text { Headache" OR "Headache, Sick" OR "Headaches, Sick" OR "Sick Headaches" OR "Abdominal Migraine" OR "Abdominal } \\
\text { Migraines" OR "Migraine, Abdominal" OR "Migraines, Abdominal" OR "Cervical Migraine Syndrome" OR "Cervical Migraine } \\
\text { Syndromes" OR "Migraine Syndrome, Cervical" OR "Migraine Syndromes, Cervical" } \\
\text { \#3 MeSH descriptor: [Migraine with Aura] explode all trees } \\
\text { \#4 "Migraine with Auras" OR "Familial Hemiplegic Migraine" OR "Familial Hemiplegic Migraines" OR "Hemiplegic- } \\
\text { Ophthalmoplegic Migraine" OR "Hemiplegic Migraine, Familial" OR "Migraine with Typical Aura" OR "Classical Migraine" } \\
\text { OR "Migraine, Classical" OR "Migraine, Classic" OR "Classic Migraine" OR "Migraine with Acute Onset Aura" OR "Acute } \\
\text { Onset Aura Migraine" OR "Migraine with Prolonged Aura" OR "Migraine, Prolonged Aura" OR "Prolonged Aura Migraine" } \\
\text { OR "Complicated Migraine" OR "Migraine, Complicated" OR "Basilar-Type Migraine" OR "Basilar Type Migraine" OR } \\
\text { "Migraine, Basilar-Type" OR "Basilar Migraine" OR "Basilar Migraines" OR "Migraine, Basilar" OR "Basilar Artery Migraine" } \\
\text { OR "Migraine, Basilar Artery" OR "Migraine Aura without Headache" OR "Typical Aura without Headache" } \\
\text { \#5 MeSH descriptor: [Migraine without Aura] explode all trees } \\
\text { \#6 "Common Migraine" OR "Common Migraines" OR "Migraines, Common" OR "Migraine, Common" } \\
\text { \#7 \#1 OR \#2 OR \#3 OR \#4 OR \#5 OR \#6 } \\
\text { \#8 MeSH descriptor: [Pizotyline] explode all trees } \\
\text { \#9 Pizotifen OR Polomigran OR Sandomigran OR BC-105 OR "BC 10 5" OR BC105 } \\
\text { \#10 \#8 OR \#9 } \\
\text { \#1 } 1 \text { \#7 AND \#10 (in Trials) (78) }\end{array}$ \\
\hline $\begin{array}{l}\text { Literatura Latino- } \\
\text { Americana em } \\
\text { Ciências da Saúde e } \\
\text { do Caribe - LILACS (via } \\
\text { Biblioteca Virtual em } \\
\text { Saúde - BVS) }\end{array}$ & $\begin{array}{l}\text { \#1 MH: "Transtornos de Enxaqueca" OR "Migraine Disorders" OR "Trastornos Migrañosos" OR } \\
\text { C10.228. } 140.546 .399 .750 \\
\text { \#2 MH: Pizotilina OR Pizotyline OR Pizotilina OR D02.886.778.580 OR D03.383.903.580 } \\
\text { \#3 \#1 AND \#2 (4) }\end{array}$ \\
\hline PsycINFO (APA) & Any Field: migraine disorders AND Any Field: Pizotyline (10) \\
\hline ClinicalTrials.gov & Pizotifen AND Migraine (0) \\
\hline WHO/ICTPR & Pizotifen AND Migraine (0) \\
\hline
\end{tabular}


Supplementary material 2. Judgments and justifications for risk of bias assessments.

\begin{tabular}{|c|c|c|c|c|c|c|c|}
\hline $\begin{array}{l}\text { Study } \\
\text { (author } \\
\text { year) }\end{array}$ & Sequence generation & $\begin{array}{l}\text { Allocation } \\
\text { concealment }\end{array}$ & $\begin{array}{l}\text { Blinding participants/ } \\
\text { personnel }\end{array}$ & Blinding outcome assessors & Incomplete outcome & $\begin{array}{l}\text { Selective } \\
\text { reporting }\end{array}$ & Other bias \\
\hline $\begin{array}{c}\text { Behan } \\
1985\end{array}$ & $\begin{array}{l}\quad \text { UNCLEAR } \\
\text { No information on } \\
\text { random sequence } \\
\quad \text { generation }\end{array}$ & $\begin{array}{c}\text { UNCLEAR } \\
\text { No } \\
\text { information } \\
\text { on allocation } \\
\text { concealment }\end{array}$ & $\begin{array}{c}\text { HIGH } \\
\text { Quote: "A randomised, } \\
\text { single-blind study" }\end{array}$ & $\begin{array}{l}\text { UNCLEAR } \\
\text { Blinding of outcome } \\
\text { assessors was unconfirmed. } \\
\text { Judgement of subjective } \\
\text { outcomes is likely to be } \\
\text { influenced by the lack of } \\
\text { blinding. }\end{array}$ & $\begin{array}{c}\text { HIGH } \\
\text { Substantial losses } \\
(26.6 \%) \text {, with } \\
\text { reasons: no data at } \\
\text { all were available } \\
\text { for } 6 \text { and a further } 2 \\
\text { did not } \\
\text { return after the } \\
\text { admission interview. } \\
\text { No ITT analysis. }\end{array}$ & $\begin{array}{l}\text { UNCLEAR } \\
\text { Unavailable } \\
\text { trial } \\
\text { protocol }\end{array}$ & $\begin{array}{c}\text { LOW } \\
\text { No other } \\
\text { potentially } \\
\text { sources of bias. }\end{array}$ \\
\hline $\begin{array}{l}\text { Behan } \\
1986\end{array}$ & $\begin{array}{l}\text { UNCLEAR } \\
\text { No information on } \\
\text { random sequence } \\
\quad \text { generation. }\end{array}$ & $\begin{array}{l}\text { UNCLEAR } \\
\text { No } \\
\text { information } \\
\text { on allocation } \\
\text { concealment }\end{array}$ & $\begin{array}{c}\text { HIGH } \\
\text { Quote: "A randomised, } \\
\text { single-blind study" }\end{array}$ & $\begin{array}{l}\text { UNCLEAR } \\
\text { Blinding of outcome } \\
\text { assessors was unconfirmed. } \\
\text { Judgement of subjective } \\
\text { outcomes is likely to be } \\
\text { influenced by the lack of } \\
\text { blinding. }\end{array}$ & $\begin{array}{c}\text { HIGH } \\
\text { Substantial losses } \\
(44 \%) \text {, with reasons: } \\
16 \text { in the naproxen, } \\
15 \text { pizotifen (due } \\
\text { to poor response, } \\
\text { adverse event, loss to } \\
\text { follow up, remission). } \\
\text { No ITT analysis. }\end{array}$ & $\begin{array}{l}\text { UNCLEAR } \\
\text { Unavailable } \\
\text { trial } \\
\text { protocol }\end{array}$ & $\begin{array}{c}\text { LOW } \\
\text { No other } \\
\text { potentially } \\
\text { sources of bias. }\end{array}$ \\
\hline $\begin{array}{l}\text { Bellavance } \\
1990\end{array}$ & $\begin{array}{l}\text { UNCLEAR } \\
\text { Quote: 'patients } \\
\text { were assigned to } \\
\text { receive, according } \\
\text { to a predetermined } \\
\text { randomization code'. } \\
\text { Comment: Insufficient } \\
\text { information on } \\
\text { random sequence } \\
\text { generation. }\end{array}$ & $\begin{array}{l}\text { UNCLEAR } \\
\text { No } \\
\text { information } \\
\text { on allocation } \\
\text { concealment }\end{array}$ & $\begin{array}{l}\text { UNCLEAR } \\
\text { Quote: "The drugs were } \\
\text { taken three times daily } \\
\text { using a double placebo } \\
\text { method." Comment: There } \\
\text { was insufficient information } \\
\text { on how blinding of } \\
\text { participants and personnel } \\
\text { was performed. }\end{array}$ & $\begin{array}{l}\text { UNCLEAR } \\
\text { Quote: "The drugs were } \\
\text { taken three times daily } \\
\text { using a double placebo } \\
\text { method." Comment: There } \\
\text { was insufficient information } \\
\text { on how blinding of outcome } \\
\text { assessors was performed. }\end{array}$ & $\begin{array}{c}\text { HIGH } \\
\text { Substantial losses } \\
\text { (16.4\%), with } \\
\text { reasons: } 7 \text { dropped } \\
\text { out due to adverse } \\
\text { reactions, } 4 \text { were lost } \\
\text { to follow-up, } 4 \text { were } \\
\text { noncompliant and } \\
10 \text { dropped out due } \\
\text { to reasons unrelated } \\
\text { to therapy. No ITT } \\
\text { analysis. }\end{array}$ & $\begin{array}{l}\text { UNCLEAR } \\
\text { Unavailable } \\
\text { trial } \\
\text { protocol }\end{array}$ & $\begin{array}{c}\text { LOW } \\
\text { No other } \\
\text { potentially } \\
\text { sources of bias. }\end{array}$ \\
\hline $\begin{array}{c}\text { Cerbo } \\
1985\end{array}$ & $\begin{array}{c}\text { UNCLEAR } \\
\text { Quote: 'i pazienti } \\
\text { sono stati assegnati } \\
\text { in maniera } \\
\text { randomizzata a due } \\
\text { gruppi, per effettuare } \\
\text { un trattamento di } \\
\text { due mesi'. Comment: } \\
\text { Insufficient information } \\
\text { on random sequence } \\
\text { generation. }\end{array}$ & $\begin{array}{l}\text { UNCLEAR } \\
\text { No } \\
\text { information } \\
\text { on allocation } \\
\text { concealment }\end{array}$ & $\begin{array}{c}\text { LOW } \\
\text { Quote: 'i farmaci erano } \\
\text { stati consegnati in boccette } \\
\text { di plastica indentiche, } \\
\text { denominate A (pizitifene) } \\
\text { e B (flunarizina). All'inizio } \\
\text { dello studio né i medici } \\
\text { né il paziente sapevano } \\
\text { quali farmaci fossero } \\
\text { presenti nelle boccette A } \\
\text { e B.'. Comment: adequate } \\
\text { blinding }\end{array}$ & $\begin{array}{l}\text { LOW } \\
\text { Quote: 'La valutazione } \\
\text { dell'effetto profilattico è } \\
\text { stata effettuata per mezzo } \\
\text { di controlli mensili dei } \\
\text { pazienti, mettendo in } \\
\text { evidenza le variazioni } \\
\text { di grequenza, intensità } \\
\text { e durata degli attachi.' } \\
\text { Comment: outcome } \\
\text { assessment was conducted } \\
\text { by the patients, that were } \\
\text { blinded by the allocation } \\
\text { group. }\end{array}$ & $\begin{array}{c}\text { LOW } \\
\text { No substantial losses } \\
(10 \%) \text {, with reasons }\end{array}$ & $\begin{array}{l}\text { UNCLEAR } \\
\text { Unavailable } \\
\text { trial } \\
\text { protocol }\end{array}$ & $\begin{array}{l}\text { UNCLEAR } \\
\text { The study did } \\
\text { not describe } \\
\text { the baseline } \\
\text { characteristics } \\
\text { between } \\
\text { groups. }\end{array}$ \\
\hline $\begin{array}{c}\text { Chitsaz } \\
2012\end{array}$ & $\begin{array}{l}\text { UNCLEAR } \\
\text { No information on } \\
\text { random sequence } \\
\text { generation. }\end{array}$ & $\begin{array}{l}\text { UNCLEAR } \\
\text { No } \\
\text { information } \\
\text { on allocation } \\
\text { concealment }\end{array}$ & $\begin{array}{c}\text { HIGH } \\
\text { Quote: 'This was a single } \\
\text { blind, randomized, } \\
\text { parallel-group study.' }\end{array}$ & $\begin{array}{c}\text { LOW } \\
\text { Quote: 'A research assistant } \\
\text { who was blind to the } \\
\text { type of intervention made } \\
\text { all evaluations.' }\end{array}$ & $\begin{array}{l}\text { UNCLEAR } \\
\text { It was not clear if } \\
\text { there were no losses } \\
\text { after randomization. }\end{array}$ & $\begin{array}{l}\text { UNCLEAR } \\
\text { Unavailable } \\
\text { trial } \\
\text { protocol }\end{array}$ & $\begin{array}{c}\text { LOW } \\
\text { No other } \\
\text { potentially } \\
\text { sources of bias. }\end{array}$ \\
\hline $\begin{array}{c}\text { Lawrence } \\
1977\end{array}$ & $\begin{array}{l}\text { UNCLEAR } \\
\text { No information on } \\
\text { random sequence } \\
\text { generation. }\end{array}$ & $\begin{array}{c}\text { UNCLEAR } \\
\text { No } \\
\text { information } \\
\text { on allocation } \\
\text { concealment }\end{array}$ & $\begin{array}{l}\text { UNCLEAR } \\
\text { Blinding of outcome } \\
\text { participants and personnel } \\
\text { was unconfirmed. } \\
\text { Judgement of subjective } \\
\text { outcomes is likely to be } \\
\text { influenced by the lack of } \\
\text { blinding. }\end{array}$ & $\begin{array}{c}\text { HIGH } \\
\text { Quote: 'Information } \\
\text { about migraine attacks } \\
\text { was recorded daily on } \\
\text { record cards'. Comment: } \\
\text { Outcomes results could be } \\
\text { influenced by this fact. }\end{array}$ & $\begin{array}{c}\text { HIGH } \\
\text { Substantial losses } \\
\text { (22\%), with reasons: } \\
\text { '5 on active treatment } \\
\text { stopped because of } \\
\text { failure to improve, } \\
\text { symptoms resolved, } \\
\text { complained of } \\
\text { depression, and } \\
\text { felt "muzzy", bad } \\
\text { tempered and was } \\
\text { excessively hungry. } \\
\text { Three patients on } \\
\text { placebo stopped } \\
\text { treatment because it } \\
\text { was ineffective. No } \\
\text { ITT analysis. }\end{array}$ & $\begin{array}{l}\text { UNCLEAR } \\
\text { Unavailable } \\
\text { trial } \\
\text { protocol }\end{array}$ & $\begin{array}{l}\text { UNCLEAR } \\
\text { The study did } \\
\text { not describe } \\
\text { the baseline } \\
\text { characteristics } \\
\text { between } \\
\text { groups. }\end{array}$ \\
\hline
\end{tabular}




\begin{tabular}{|c|c|c|c|c|c|c|c|}
\hline $\begin{array}{l}\text { Louis } \\
1982\end{array}$ & $\begin{array}{l}\text { UNCLEAR } \\
\text { No information on } \\
\text { random sequence } \\
\text { generation. }\end{array}$ & $\begin{array}{c}\text { UNCLEAR } \\
\text { No } \\
\text { information } \\
\text { on allocation } \\
\text { concealment }\end{array}$ & $\begin{array}{l}\text { UNCLEAR } \\
\text { Blinding of outcome } \\
\text { participants and personnel } \\
\text { was unconfirmed. } \\
\text { Judgement of subjective } \\
\text { outcomes is likely to be } \\
\text { influenced by the lack of } \\
\text { blinding. }\end{array}$ & $\begin{array}{c}\text { UNCLEAR } \\
\text { Blinding of outcome } \\
\text { assessors was unconfirmed. } \\
\text { Judgement of subjective } \\
\text { outcomes is likely to be } \\
\text { influenced by the lack of } \\
\text { blinding. }\end{array}$ & $\begin{array}{l}\text { LOW } \\
\text { No substantial losses } \\
(8 \%) \text {, with reasons. }\end{array}$ & $\begin{array}{l}\text { UNCLEAR } \\
\text { Unavailable } \\
\text { trial } \\
\text { protocol }\end{array}$ & $\begin{array}{c}\text { LOW } \\
\text { No other } \\
\text { potentially } \\
\text { sources of bias. }\end{array}$ \\
\hline $\begin{array}{c}\text { Rascol } \\
1986\end{array}$ & $\begin{array}{l}\text { LOW } \\
\text { Quote: 'According } \\
\text { to a computer-made } \\
\text { randomization list'. } \\
\text { Comment: Insufficient } \\
\text { information on } \\
\text { random sequence } \\
\text { generation. }\end{array}$ & $\begin{array}{c}\text { UNCLEAR } \\
\text { No } \\
\text { information } \\
\text { on allocation } \\
\text { concealment }\end{array}$ & $\begin{array}{l}\text { UNCLEAR } \\
\text { Blinding of outcome } \\
\text { participants and personnel } \\
\text { was unconfirmed. } \\
\text { Judgement of subjective } \\
\text { outcomes is likely to be } \\
\text { influenced by the lack of } \\
\text { blinding. }\end{array}$ & $\begin{array}{c}\text { UNCLEAR } \\
\text { Blinding of outcome } \\
\text { assessors was unconfirmed. } \\
\text { Judgement of subjective } \\
\text { outcomes is likely to be } \\
\text { influenced by the lack of } \\
\text { blinding. }\end{array}$ & $\begin{array}{c}\text { LOW } \\
\text { No substantial losses } \\
\text { (8.5\%), with reasons. }\end{array}$ & $\begin{array}{l}\text { UNCLEAR } \\
\text { Unavailable } \\
\text { trial } \\
\text { protocol }\end{array}$ & $\begin{array}{c}\text { LOW } \\
\text { No other } \\
\text { potentially } \\
\text { sources of bias. }\end{array}$ \\
\hline
\end{tabular}

Supplementary material 3. Summary of findings table: pizotifen versus placebo.

Pizotifen compared to placebo for migraine

Patient or population: migraine

Setting: outpatient

Intervention: pizotifen

Comparison: placebo

\begin{tabular}{|c|c|c|c|c|c|c|}
\hline \multirow{2}{*}{ Outcomes } & \multicolumn{2}{|c|}{ Anticipated absolute effects* $(95 \% \mathrm{Cl})$} & \multirow{2}{*}{$\begin{array}{l}\text { Relative effect } \\
\qquad(95 \% \mathrm{CI})\end{array}$} & \multirow{2}{*}{$\begin{array}{l}\text { No of participants } \\
\text { (studies) }\end{array}$} & \multirow{2}{*}{$\begin{array}{c}\text { Certainty of the evidence } \\
\text { (GRADE) }\end{array}$} & \multirow{2}{*}{ Comment: } \\
\hline & Risk with placebo & Risk with Pizotifen & & & & \\
\hline $\begin{array}{l}\text { Frequency, intensity and } \\
\text { duration of migraine episodes } \\
\text { assessed with: Headache } \\
\text { index } \\
\text { follow up: mean } 3 \text { months }\end{array}$ & 143 per 1.000 & $\begin{array}{l}857 \text { per } 1.000 \\
(233 \text { to } 1.000)\end{array}$ & $\begin{array}{l}\operatorname{RR~} 6.00 \\
\text { (1.63 to } 22.03)\end{array}$ & $\begin{array}{l}28 \\
\text { (1 RCT) }\end{array}$ & 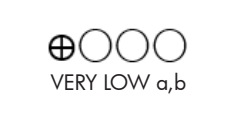 & \\
\hline $\begin{array}{l}\text { Adverse events (weight gain) } \\
\text { follow up: mean } 3 \text { months }\end{array}$ & 114 per 1.000 & $\begin{array}{l}219 \text { per } 1.000 \\
\text { (34 to } 1.000)\end{array}$ & $\begin{array}{l}\text { RR } 1.92 \\
(0.30 \text { to } \\
12.38)\end{array}$ & $\begin{array}{c}142 \\
(2 \mathrm{RCTs})\end{array}$ & $\underset{V E R Y}{\oplus \bigcirc \bigcirc O} \bigcirc$ & \\
\hline
\end{tabular}

*The risk in the intervention group (and its $95 \%$ confidence interval) is based on the assumed risk in the comparison group and the relative effect of the intervention (and its $95 \% \mathrm{Cl}$ ). $\mathrm{Cl}$ : Confidence interval; RR: Risk ratio

GRADE Working Group grades of evidence

High certainty: We are very confident that the true effect lies close to that of the estimate of the effect

Moderate certainty: We are moderately confident in the effect estimate: The true effect is likely to be close to the estimate of the effect, but there is a possibility that it is substantially

Lifferent

Very low certainty: We have very little confidence in the effect estimate: The true effect is likely to be substantially different from the estimate of effect

\section{Explanations}

a. We downgraded 2 levels due to methodological limitations (unclear risk for selection and performance bias; and high risk for detection and attrition bias.

b. We downgraded 2 levels due to a wide $\mathrm{Cl}$ and small sample size.

c. We downgraded one level due to substantial heterogeneity $(12=67 \%)$ 